\title{
Evaluasi Pelaksanaan Pengarusutamaan Gender (PUG) kota Pekanbaru
}

\author{
Siti Soleha1, \& Afriyanni2* \\ ${ }^{1}$ Badan Perencanaan Pembangunan Daerah Kota Pekanbaru, Indonesia \\ 2Badan Penelitian dan Pengembangan Kota Pekanbaru, Indonesia
}

\begin{abstract}
Abstrak Penelitian ini bertujuan untuk untuk mendeskripsikan dan mengevaluasi pelaksanaan Pengarusutamaan Gender (PUG) di Kota Pekanbaru. Penelitian ini menggunakan pendekatan deskriptif kualitatif untuk mengevaluasi penyelenggaraan PUG Kota Pekanbaru berdasarkan Peraturan Menteri Pemberdayaan Perempuan dan Perlindungan Anak Nomor 7 Tahun 2018 . Teknik pengumpulan data dilakukan dengan studi dokumentasi dan wawancara mendalam. Untuk menguji keabsahan dan validitas data digunakan teknik triangulasi sumberdata dan triangulasi teknik. Teknik analisis data dilakukan dengan cara reduksi data, penyajian data dan penarikan kesimpulan. Hasil penelitian menunjukkan Capaian indikator pembangunan gender di Kota Pekanbaru baik dari Indeks Pembangunan Manusia (IPM) dan Indeks Pembangunan Gender (IPG) sudah berada di atas level nasional dan provinsi namun dari Indeks Disparitas Gender (IDG) masih perlu menjadi perhatian pemerintah. Selanjutnya berdasarkan Peraturan Menteri Pemberdayaan Perempuan dan Perlindungan Anak Nomor 7 Tahun 2018, Pemerintah Kota Pekanbaru telah memenuhi syarat kelembagaan PUG namun hasilnya belum optimal. Hambatan yang dihadapi dalam pelaksanaan PUG yaitu belum kuatnya regulasi yang mengatur pelaksanaan Gender serta masih lemahnya komitmen pimpinan OPD untuk melaksanakan PUG. Penelitian ini merekomendasikan perlunya menetapkan Peraturan Daerah tentang PUG, mendorong munculnya Inovasi - inovasi mendukung PUG dan penguatan sumberdaya baik SDM dan anggaran.
\end{abstract}

Kata kunci: evaluasi; gender; pengarusutamaan gender

\begin{abstract}
This study aims to describe and evaluate the implementation of Gender Mainstreaming (PUG) in Pekanbaru City. This study uses a qualitative descriptive approach to evaluate the implementation of PUG in Pekanbaru City based on the Minister of Women's Empowerment and Child Protection Regulation Number 7 of 2018. Data collection techniques were carried out with documentation studies and in-depth interviews. To test the validity and validity of the data used data source triangulation techniques and triangulation techniques. The data analysis technique was carried out through data reduction, data presentation, and concluding. The results showed that the achievement of gender development indicators in Pekanbaru City, both from the Human Development Index (IPM) and the Gender Development Index (GIP) were already above the national and provincial levels, but the Gender Disparity Index (IDG) still needed the government's attention. Furthermore, based on the Regulation of the Minister of Women's Empowerment and Child Protection Number 7 of 2018, the Pekanbaru City Government has fulfilled the PUG institutional requirements but the results have not been optimal. The obstacles faced in the implementation of PUG are the lack of strong regulations governing the implementation of Gender and the weak commitment of OPD leaders to implement PUG. This study recommends the need to stipulate a Regional Regulation on PUG, encourage the emergence of innovations to support PUG, and strengthen resources, both human resources and budget.
\end{abstract}

Keywords: evaluation; implementation; gender mainstreaming

JEL Classification: 021 ; 015 


\section{PENDAHULUAN}

Sejak dikeluarkannya Peraturan Presiden Nomor 9 Tahun 2000 tentang Pengarusutamaan Gender di Indonesia, keadilan dan kesetaraan gender masih menjadi permasalahan pembangunan yang belum dapat diselesaikan. Berbagai upaya telah dilakukan oleh pemerintah secara berjenjang untuk mewujudkan kesetaraan gender namun hasilnya belum tercapai secara optimal bahkan memperlembar kesenjangan sosial dan ketidakadilan gender (Hasanah \& Musyafak, 2018), (Kertati, 2021).

The Global Gender Gap Index 2020 melaporkan Indonesia berada pada peringkat 85 dari 153 negara dan masih jauh tertinggal dari negara tetangga lainnya seperti Laos, Singapura dan Thailand (Normadilla \& Erlina, 2020). Menguatkan laporan tersebut, hasil kajian Badan Pusat Statistik (BPS) menemukan Indeks Ketimpangan Gender (IKG) Indonesia nilainya masih cukup tinggi (Tusianti, 2020). Selanjutnya ditinjau dari capaian IPG level provinsi pada tahun 2019, masih terdapat $19(55,88 \%)$ provinsi dengan capaian IPG di bawah rata-rata nasional dan hanya 5 atau $14,70 \%$ provinsi yang pencapaiannya berada di atas rata-rata nasional. Data-data tersebut menunjukkan masih ada kesenjangan akses, partisipasi, kontrol dan manfaat antara laki-laki dan perempuan dalam pembangunan di banyak daerah (Dini et al., 2020).

Gender adalah sebuah konstruksi sosial terhadap laki-laki dan perempuan yang bersifat spesifik, kontekstual dan situasional (Dzuhayatin, 2012), (Hanafie, 2017) menurut tempat, waktu, suku bangsa, budaya, status sosial, agama, ideologi, politik dan ekonomi (Rahayu, 2017). Pembedaan gender sebagai akibat konstruksi sosial tersebut melahirkan diskriminasi dan ketidakadilan gender (Apriliandra \& Krisnani, 2021). Diskriminasi tersebut terjadi hampir pada semua aspek antara lain pendidikan, pekerjaan, akses terhadap sumber daya, ekonomi, kekuasaan, dan partisipasi politik (Vera \& Sitorus, 2010). Kondisi tersebut akhirnya berdampak negatif terhadap pembangunan ekonomi.

Pengarusutamaan gender (PUG) merupakan salah satu strategi untuk mengatasi masalah ketidakadilan gender (Annisa et al., 2021), (Ylöstalo \& Ylöstalo, 2016). PUG adalah konsep, prinsip dan masalah kesetaraan gender yang dintegrasikan ke dalam kebijakan, program, dan kegiatan pembangunan mulai dari perencanaan penganggaran, pelaksanaan, pemantauan, dan evaluasi (Santoso, 2016), (Dzuhayatin, 2012) (Kertati, 2019) pada setiap level pemerintahan (Bappenas, 2020).

Faktanya belum seluruh konsep dan pelaksanaan kebijakan publik pro gender (Darwin, 2006) bahkan PUG dalam pelaksanaannya hanya pemindahan diskriminasi dari ranah domestik ke ranah publik (Luh et al., 2019), (Musarrofa, 2019) menjadi bentuk eksploitasi dan beban ganda terhadap perempuan (Santoso, 2016), (Tamami, 2015). Akibatnya pelaksanaan PUG belum optimal (Azmy \& Pertiwi, 2021).

Upaya mengatasi permasalahan ketidakadilan gender telah dilakukan secara berkelanjutan baik melalui pendekatan struktural (hukum dan kebijakan) sosial, 
maupun pendidikan. Dalam tataran hukum beberapa regulasi dan keputusan yang mendukung pelaksanaan PUG telah dikeluarkan pemerintah sebagai bentuk komitmen untuk mewujudkan kesetaraan gender dalam pembangunan. Penetapan Instruksi Presiden Nomor 9 Tahun 2000 merupakan implementasi ratifikasi Indonesia terhadap berbagai komitmen global. Instruksi Presiden tersebut meskipun secara legalitas belum kuat namun telah menjadi landasan pijak bagi lahirnya regulasi dan kebijakan lain yang mendukung penerapan PUG dan merupakan mandat bagi instansi pemerintah untuk mengintegrasikan gender ke dalam semua rencana dan program-program pembangunan.

Selanjutnya pada tahun 2012, pengintegrasian PUG kedalam proses perencanaan dan penganggaran kembali diperkuat dengan terbit Surat Edaran Bersama antara 4 (empat) Kementerian, yakni Kementerian Perencanaan Pembangunan Nasonal (PPN)/Bappenas, Kementerian Keuangan, Kementerian Dalam Negeri dan Kementerian Pemberdayaan Perempuan dan Perlindungan Anak (KPP dan PA) Nomer 270/M.PPN/11/2012; Nomer SE33/MK.02/2012; Nomer 050/4379A/SJ dan SE 46/MPP-PA/11/2012 tentang Strategi Nasional Percepatan Pengarusutamaan Gender (PUG) melalui Perencanaan dan Penganggaran yang Responsif Gender (PPRG).

Tindak lanjut dari komitmen tersebut dalam tataran kebijakan dapat dilihat dalam Dokumen Rencana Pembangunan Jangka Menengah Nasional (RPJMN) th 2020-2024 yang secara tegas menyebutkan bahwa gender sebagai salah satu strategi yang harus diterapkan mulai dari tahun 2020 hingga 2024. Maksud penegasan tersebut gender menjadi prioritas nasional yang harus dicapai sesuai dengan target yang ditetapkan dan ditindaklanjuti oleh pemerintah daerah dalam bentuk RPJM daerah, Renstra perangkat daerah. Dokumen lain yang mengintegrasikan PUG adalah Dokumen Pembangunan Berkelanjutan (Sustainable Development Goals/SDGs) yang memasukkan PUG dalam tujuan kelima sebagai agenda Pembangunan Berkelanjutan.

Untuk mengetahui sejauhmana capaian pelaksanaan PUG di lingkup pemerintah daerah, Kementerian Pemberdayaan Perempuan dan Perlindungan Anak (KemenPPA) menetapkan PermenPPA Nomor 7 Tahun 2018 tentang Perubahan atas Peraturan Menteri Pemberdayaan Perempuan dan Perlindungan Anak Nomor 9 Tahun 2015 tentang Indikator Pemantauan dan Evaluasi Pelaksanaan Pembangunan Pemberdayaan Perempuan dan Perlindungan Anak. Evaluasi dilakukan terhadap indikator kelembagaan dan hasil pelaksanaan PUG. Indikator kelembagaan PUG merupakan prasyarat yang harus dipenuhi dalam pelaksanaan PUG, yaitu: Komitmen; kebijakan; kelembagaan; sumberdaya manusia dan anggaran; data terpilah, sistem informasi dan bahan informasi; metode dan tool serta partisipasi masyarakat. Evaluasi tersebut diharapkan dapat menjadi pedoman bagi Pemerintah Daerah untuk mengoptimalkan pencapaian target pelaksanaan PUG dalam pembangunan daerah.

Sehubungan dengan uraian tersebut diatas, Pemerintah Kota Pekanbaru sebagai salah satu Pemerintah kota di Indonesia yang menerapkan pelaksanaan PUG dalam pembangunan daerah perlu melakukan evaluasi terhadap pelaksanaan 
PUG mengacu pada PermenPPA Nomor 7 Tahun 2018. Evaluasi dimaksud bertujuan untuk mengetahui sejauhmana pemenuhan indikator kelembagaan yang menjadi prasyarat pelaksanaan PUG dan hambatan apa saja yang dihadapi dalam pemenuhan prasyarat tersebut. Penelitian ini mengacu pada hasil penelitian Kertati (2019) yang meneliti tentang evaluasi penyelenggaraan PUG Kota Semarang namun lokus penelitian ini berbeda dengan penelitian sebelumnya.

\section{METODE}

Penelitian ini dilaksanakan di Kota Pekanbaru. Penelitian ini menggunakan pendekatan deskriptif kualitatif untuk menggambarkan pelaksanaan kebijakan pengarusutamaan gender di Kota Pekanbaru. Pengumpulan data dilakukan dengan studi dokumentasi dan wawancara. Studi dokumentasi dilakukan terhadap dokumen perencanaan dan penganggaran (Renja dan Renstra SKPD, RKPD, RPJMD dan APBD), laporan, regulasi, pedoman dan artikel terkait PUG sedangkan wawancara mendalam dilakukan terhadap informan kunci yang dipilih secara purposive artinya pemilihan informan dengan mempertimbangkan kriteria tertentu yaitu orang/ pejabat yang dipandang mengetahui PUG dan menjadi anggota Pokja PUG. Untuk menguji validitas data dilakukan melalui teknik triangulasi sumber data dan metode. Adapun informan dalam penelitian ini adalah pejabat yang membidangi pengarusutamaan gender di DP3A, pejabat terkait di Badan Perencanaan Pembangunan Daerah (Bappeda), Badan Pengelolaan Keuangan Daerah dan Aset (BPKAD) dan Inspektorat.

Teknis analisis data yang digunakan dalam penelitian ini adalah teknik analisa data kualitatif dengan cara reduksi data, penyajian data, interpretasi data dan penarikan kesimpulan. Data yang terkumpul akan dipilih dan dipilah sesuai dengan tema dan pola tertentu untuk memberikan gambaran jelas tentang pelaksanaan PUG di Kota Pekanbaru. Data yang terkumpul dari hasil studi dokumentasi disajikan dalam bentuk tabel, grafik dan gambar sedangkan hasil wawancara disajikan dalam bentuk narasi. Selanjutnya dilakukan interpretasi data dan penarikan kesimpulan.

\section{HASIL DAN PEMBAHASAN}

\section{Deskripsi Pembangunan Berbasis Gender di Kota Pekanbaru}

Deskripsi pembangunan yang berperspektif gender di Kota Pekanbaru dalam tulisan ini digambarkan dengan indikator Indeks Pembangunan Manusia, Indeks Pembangunan Gender (IPG) dan Indeks Pemberdayaan Gender (IDG). IPG merupakan perbandingan antara Indeks Pembangunan Manusia (IPM) laki-laki dan IPM perempuan yang ditinjau dari aspek pendidikan, kesehatan dan ekonomi. Pembangunan gender dinilai berhasil jika angka IPG yang dicapai mendekati nilai 100. IDG merupakan persentase sumbangan perempuan dalam ekonomi, politik dan manajerial. Selain kedua indikator tersebut terdapat Indeks ketimpangan gender (IKG) menggambarkan kerugian akibat pembangunan yang tidak responsif 
gender ditinjau dari aspek kesehatan, pemberdayaan dan akses terhadap pasar kerja (Karyono et al., 2018).

Tabel 1 IPG, IDG dan IKG Kota Pekanbaru, Provinsi Riau dan Indonesia Tahun 2011 s.d 2020

\begin{tabular}{lrllllllllll}
\hline \multirow{2}{*}{ Wilayah } & \multicolumn{10}{c}{ Tahun } \\
\cline { 2 - 11 } & $\mathbf{2 0 1 1}$ & $\mathbf{2 0 1 2}$ & $\mathbf{2 0 1 3}$ & $\mathbf{2 0 1 4}$ & $\mathbf{2 0 1 5}$ & $\mathbf{2 0 1 6}$ & $\mathbf{2 0 1 7}$ & $\mathbf{2 0 1 8}$ & $\mathbf{2 0 1 9}$ & $\mathbf{2 0 2 0}$ \\
\hline Pekanbaru & & & & & & & & & & & \\
IPG & 90,76 & 90,77 & 91,00 & 91,83 & 92,36 & na & 92,86 & 92,97 & 93,12 & 93,01 \\
IDG & 62,73 & 61,80 & 63,54 & 64,08 & 64,45 & na & 65,83 & 61,05 & 67,79 & 69,23 \\
IKG & 77,71 & 77,94 & 78,16 & 78,42 & 79,32 & 79,69 & 79,97 & 80,66 & 81,35 & 81,32 \\
Riau & & & & & & & & & & \\
IPG & 85,74 & 86,29 & 86,74 & 87,62 & 87,75 & 88,04 & 88,17 & 88,37 & 88,43 & 88,14 \\
IDG & 65,34 & 69,05 & 69,78 & 74,11 & 74,59 & 75,19 & 75,36 & 75,73 & 69,17 & 68,7 \\
IKG & 68,90 & 69,15 & 69,91 & 70,33 & 70,84 & 71,20 & 71,79 & 72,44 & 73,00 & 72,71 \\
Indonesia & & & & & & & & & & \\
IPG & 89,52 & 90,07 & 90,19 & 90,34 & 91,03 & 90,82 & 90,96 & 90,99 & 91,07 & 91,06 \\
IDG & 69,14 & 70,07 & 70,46 & 70,68 & 70,83 & 71,39 & 71,74 & 72,1 & 75,24 & 75,57 \\
IKG & 67,09 & 67,70 & 68,31 & 68,90 & 69,55 & 70,18 & 70,81 & 71,39 & 71,92 & 71,94 \\
\hline
\end{tabular}

Sumber : https://bps.go.id, 2021

Selama periode 2011 s.d 2020, nilai IPG, IDG dan IKG Pekanbaru menunjukkan tren kenaikan namun tren kenaikan tersebut belum cukup signifikan sebagaimana ditunjukkan pada Tabel 1. Kondisi tersebut tidak jauh berbeda dengan provinsi dan nasional. Nilai IPG dan IKG Kota Pekanbaru lebih tinggi dibandingkan provinsi dan nasional sebaliknya IDGnya lebih rendah dibandingkan provinsi dan nasional. IPG Kota Pekanbaru mencapai nilai yang lebih baik karena mendekati 100 persen namun nilai IKG yang cukup tinggi berkolerasi dengan IDG yang rendah. Kondisi ini perlu menjadi perhatian pemerintah Kota Pekanbaru agar lebih menfokuskan pemberdayaan gender khususnya pemberdayaan terhadap perempuan dalam pembangunan. 
Tabel 2 IPG dan Komponennya menurut Kabupaten/Kota Tahun 2019

\begin{tabular}{|c|c|c|c|c|c|c|c|c|c|c|c|}
\hline \multirow[t]{2}{*}{ Provinsi/Kabupaten/Kote } & \multicolumn{2}{|c|}{$\begin{array}{c}\text { Angka Harapan } \\
\text { Hidup (AHH) } \\
\text { (Tahun }\end{array}$} & \multicolumn{2}{|c|}{$\begin{array}{c}\text { Harapan Lama } \\
\text { Sekolah } \\
\text { (HLS)(Tahun ) }\end{array}$} & \multicolumn{2}{|c|}{$\begin{array}{c}\text { Rata-rata Lama } \\
\text { Sekolah (RLS) } \\
\text { (Tahun) }\end{array}$} & \multicolumn{2}{|c|}{$\begin{array}{l}\text { Pengeluaran } \\
\text { Perkapita yang } \\
\text { Disesuaikan } \\
\text { (PPP) (Ribu } \\
\text { Rupiah) }\end{array}$} & \multicolumn{2}{|c|}{ IPM } & \multirow[t]{2}{*}{ IPG } \\
\hline & $\mathbf{L}$ & $\mathbf{P}$ & $\mathbf{L}$ & $\mathbf{P}$ & $\mathbf{L}$ & $\mathbf{P}$ & $\mathbf{L}$ & $\mathbf{P}$ & $\mathbf{L}$ & $\mathbf{P}$ & \\
\hline Kuantan Singingi & 66,40 & 70,37 & 12,87 & 13,57 & 8,82 & 8,34 & 16072 & 8155 & 74,58 & 67,55 & 90,57 \\
\hline Indragiri Hulu & 68,17 & 72,12 & 12,10 & 12,85 & 8,34 & 7,90 & 16876 & 6724 & 74,43 & 65,00 & 87,33 \\
\hline Indra Giri Hilir & 65,63 & 69,58 & 11,90 & 12,29 & 7,50 & 6,94 & 17021 & 5243 & 71,88 & 59,35 & 82,57 \\
\hline Pelalawan & 69,02 & 72,93 & 11,96 & 12,21 & 8,91 & 8,15 & 19196 & 8652 & 76,58 & 67,78 & 88,51 \\
\hline Siak & 69,02 & 72,93 & 12,89 & 12,75 & 9,83 & 9,45 & 19173 & 8695 & 78,80 & 69,80 & 88,58 \\
\hline Kampar & 68,62 & 72,56 & 13,15 & 13,61 & 9,54 & 8,96 & 16995 & 8326 & 77,42 & 69,55 & 89,33 \\
\hline Rokan Hulu & 67,86 & 71,80 & 13,36 & 12,82 & 8,74 & 8,10 & 17459 & 5558 & 76,48 & 62,81 & 82,13 \\
\hline Bengkalis & 69,10 & 73,01 & 12,80 & 13,75 & 9,74 & 9,08 & 17582 & 8408 & 77,85 & 70,13 & 90,08 \\
\hline Rokan Hilir & 68,14 & 72,08 & 12,35 & 13,22 & 8,62 & 7,88 & 15244 & 5620 & 74,15 & 63,19 & 85,22 \\
\hline Kepulauan Meranti & 65,50 & 69,44 & 12,78 & 12,96 & 8,09 & 7,04 & 12708 & 5763 & 70,96 & 61,17 & 86,20 \\
\hline Kota Pekanbaru & 70,24 & 74,09 & 15,37 & 15,30 & 11,68 & 11,22 & 21887 & 13503 & 85,41 & 79,53 & 93,12 \\
\hline Kota Dumai & 68,81 & 72,73 & 12,90 & 13,25 & 10,06 & 9,62 & 18062 & 9346 & 78,46 & 71,29 & 90,86 \\
\hline Riau & 69,92 & 73,43 & 12,88 & 13,40 & 9,30 & 8,75 & 16833 & 7542 & 77,35 & 68,40 & 88,43 \\
\hline Indonesia & 69,44 & 73,33 & 12,87 & 13,03 & 8,81 & 7,89 & 15866 & 9244 & 75,96 & 69,18 & 91,07 \\
\hline
\end{tabular}

Sumber: Pembangunan Indonesia Berbasis Gender, 2020

Selanjutnya apabila ditinjau dari komponen pembentuk IPG, terlihat bahwa lakilaki masih mendominasi dari aspek pendidikan (HLS dan RLS) dan ekonomi (PPP) namun perempuan lebih unggul pada aspek kesehatan $(\mathrm{AHH})$. Perbedaan capaian yang paling besar terdapat pada aspek ekonomi. Kondisi ini merata terjadi pada semua level wilayah. Apabila ditinjau dari capaian komponen IPG antar wilayah kab/kota di Provinsi Riau, Kota Pekanbaru memiliki capaian terbaik diseluruh Provinsi Riau bahkan melebihi capaian Provinsi dan nasional.

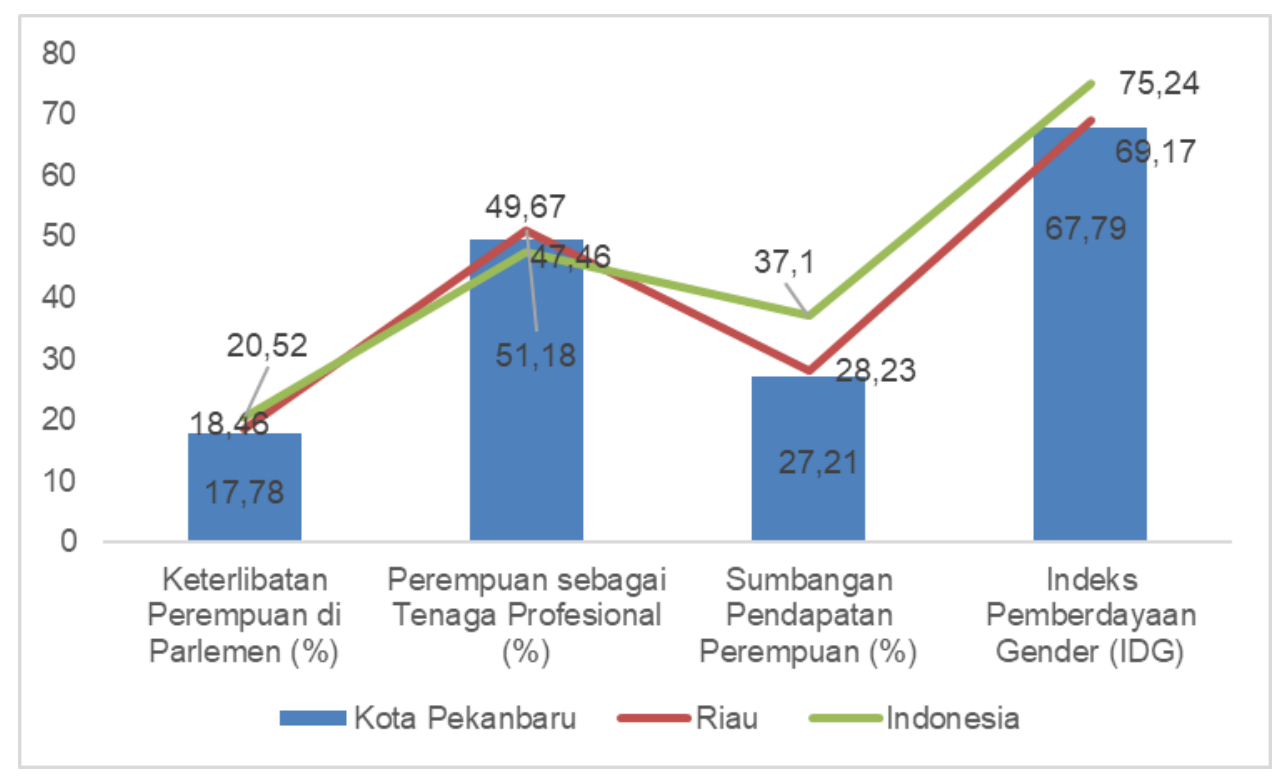

Gambar 1. Capaian Indikator IDG Kota Pekanbaru, Provinsi Riau dan Nasional Tahun 2019 Sumber: Pembangunan Manusia Berbasis Gender, 2020

Gambar 1 memperlihatkan, capaian indikator IDG Kota Pekanbaru, Provinsi Riau dan Nasional. Jika ditinjau dari capaian komponen penyusun IDG, terlihat bahwa persentase perempuan sebagai tenaga profesional lebih baik dibandingkan 
nasional namun masih berada dibawah nilai provinsi sedangkan dua komponen lainnya, yaitu keterlibatan perempuan di parlemen dan sumbangan pendapatan perempuan masih perlu mendapat perhatian pemerintah. Kondisi tersebut sama dengan temuan (Roza \& Lutfi., 2016).

Representasi politik yang rendah merupakan sinyal bahwa afirmasi 30 persen perempuan di parlemen belum mampu memenuhi harapan (Arenawati et al., 2020) dan mampu mempengaruhi pengambilan kebijakan yang berisukan gender di parlemen (Santi, 2020), (Hidayah, 2008). Sementara itu (Wisnujati, 2020) berpendapat bahwa kesetaraan gender dalam perekonomian akan sulit terwujud jika masih terjadi diskriminasi gender di sektor tersebut. Penyebab dari segala diskriminasi tersebut menurut (Apriliandra \& Krisnani, 2021) adalah masih melekatnya budaya patriarki. Pendapat tersebut kemudian dilengkapi oleh (Tawakkal et al., 2019) yang menambahkan faktor partisipasi, akses, kontrol dan ekonomi sebagai penyebab kesenjangan gender.

\section{Evaluasi Pelaksanaan PUG : Pemenuhan Indikator Kelembagaan PUG}

1. Komitmen dan Dukungan Politik

Salah satu faktor yang mendukung keberhasilan pelaksanaan suatu kebijakan adalah adanya komitmen dan dukungan politik dari pemangku kepentingan di daerah. Bentuk komitmen tersebut salah satunya diwujudkan melalui penetapan regulasi yang mendukung pelaksanaan kebijakan. Berdasarkan Peraturan Menteri Pemberdayaan Perempuan dan Perlindungan Anak Nomor 7 Tahun 2018, maka kriteria tertinggi pencapaian komitmen pelaksanaan PUG adalah regulasi pelaksanaan PUG dalam bentuk Peraturan Daerah. Regulasi dalam bentuk perda tersebut memungkinkan dukungan secara penuh baik oleh pihak legislatif dan eksekutif khususnya dalam kebijakan anggaran dan kebijakan lain terkait gender. Namun dalam pelaksanaannya Pemerintah Kota Pekanbaru menetapkan Peraturan Walikota Pekanbaru Nomor 41 Tahun 2016 Tentang Pelaksanaan Pengarusutamaan Gender dalam Pembangunan Daerah sebagai dasar pelaksanaan PUG di Kota Pekanbaru.

Regulasi tersebut kemudian ditindaklanjuti kedalam beberapa peraturan teknis, seperti Peraturan Walikota Pekanbaru Nomor 41 Tahun 2018 tentang Rencana Aksi Pengarusutamaan Gender Kota Pekanbaru, Surat Keputusan Walikota Pekanbaru Nomor 228 Tahun 2020 tentang Tim Kelompok Kerja Pengarusutamaan Gender (Pokja PUG) Kota Pekanbaru, Surat Kepala Bappeda Kota Pekanbaru Nomor 050/BAppeda-Sekr/1432/2019 Tahun 2019 tentang Penyusunan Rancangan Penganggaran Responsif Gender (PPRG).

\section{Kebijakan PUG}

Pengintegrasian PUG kedalam dokumen perencanaan (RPJMD, RKPD, Renstra dan Renja) dan penganggaran (RKA/RAPBD) diharapkan mampu mewujudkan keadilan gender (Annisa et al., 2021). Pengintegrasian PUG kedalam dokumen perencanaan jangka menengah dapat dilihat dari visi, misi, tujuan dan sasaran sebagaimana terlihat pada Tabel 1. Berdasarkan dokumen tersebut, target akhir yang akan dicapai oleh Pemerintah Kota Pekanbaru dalam upaya peningkatan 
pengarusutamaan gender dan perlindungan anak adalah IPG dengan nilai 94,3. Jika melihat target pencapaian IPG Kota Pekanbaru pada tahun 2020 yaitu sebesar 93,01 maka dalam jangka 2 (dua) tahun, Pemerintah Kota Pekanbaru harus meningatkan IPG sebesar 0,11 poin.

Tabel 3 Pengintegrasian PUG dalam RPJMD Kota Pekanbaru 2017-2022

\begin{tabular}{|c|c|c|c|c|}
\hline \multicolumn{4}{|c|}{ Visi : "Terwujudnya Pekanbaru Sebagai Smart City Madani” } \\
\hline Visi 1 & Tujuan 1 & Sasaran 3 & $\begin{array}{c}\text { Indikator } \\
\text { Sasaran }\end{array}$ & $\begin{array}{c}\text { Target } \\
\text { Akhir } \\
\text { RPJMD }\end{array}$ \\
\hline $\begin{array}{c}\text { Meningkatkan Sumber } \\
\text { Daya Manusia (SDM) } \\
\text { yang Bertaqwa, Mandiri, } \\
\text { Tangguh dan Berdaya } \\
\text { Saing Tinggi }\end{array}$ & $\begin{array}{c}\text { Mewujudkan } \\
\text { Sumber Daya } \\
\text { Mang Berkualitas }\end{array}$ & $\begin{array}{c}\text { Meningkatnya } \\
\text { pengarusutamaan } \\
\text { gender dan } \\
\text { perlindungan anak }\end{array}$ & $\begin{array}{c}\text { Indeks } \\
\text { Pembangunan } \\
\text { Gender (IPG) }\end{array}$ & 94,3 \\
\hline
\end{tabular}

Sumber: RPJMD Kota Pekanbaru 2017-2022

Selanjutnya pengintegrasian PUG kedalam program dan kegiatan dokumen jangka pendek baik dalam RKPD maupun RKA OPD baru dilaksanakan oleh 22 OPD (48,89\%) di lingkup pemerintah Kota Pekanbaru. Berdasarkan hasil wawancara dengan pejabat terkait di Bappeda dan DP3A disimpulkan bahwa Pengintegrasian dan PUG dalam perencanaan dan penganggaran belum dianggap penting oleh SKPD sehingga kegiatan-kegiatan yang mendukung pelaksanaan PUG seperti pelatihan, sosialisasi dan advokasi PUG di internal SKPD belum menjadi perhatian. Kondisi ini sama dengan temuan Muhartono, (2020) disebabkan karena program perencanaan berbasis PUG tidak dianggap penting secara sektoral, unit maupun program. Padahal menurut Harya (2018) tahap penyusunan Renja/RKPD sampai penetapan DPA SKPD merupakan fase kritis pengintegrasian PUG karena pada tahap ini dirumuskan kelompok sasaran program dan kegiatan yang disusun.

\section{Kelembagaan PUG}

Secara kelembagaan, PUG dikelola oleh Dinas P3A yang berperan dalam perumusan dan penetapan kelembagaan PUG di Kota Pekanbaru. Berdasarkan nomenklatur kelembagaan DP3A sebagaimana tertuang dalam Peraturan Daerah Nomor 5 Tahun 2020 dan Perwako Nomor 228 Tahun 2020, PUG secara khusus dikelola oleh pejabat setingkat eselon III yaitu Bidang Pengarustamaan Gender dan Pemberdayaan Perempua. Bidang ini terdiri dari 3 (tiga) seksi, yaitu Seksi PUG, Seksi Pemberdayaan Perempuan dan Seksi Kelembagaan Pemberdayaan Perempuan sebagaimana terlihat pada Gambar 2. 


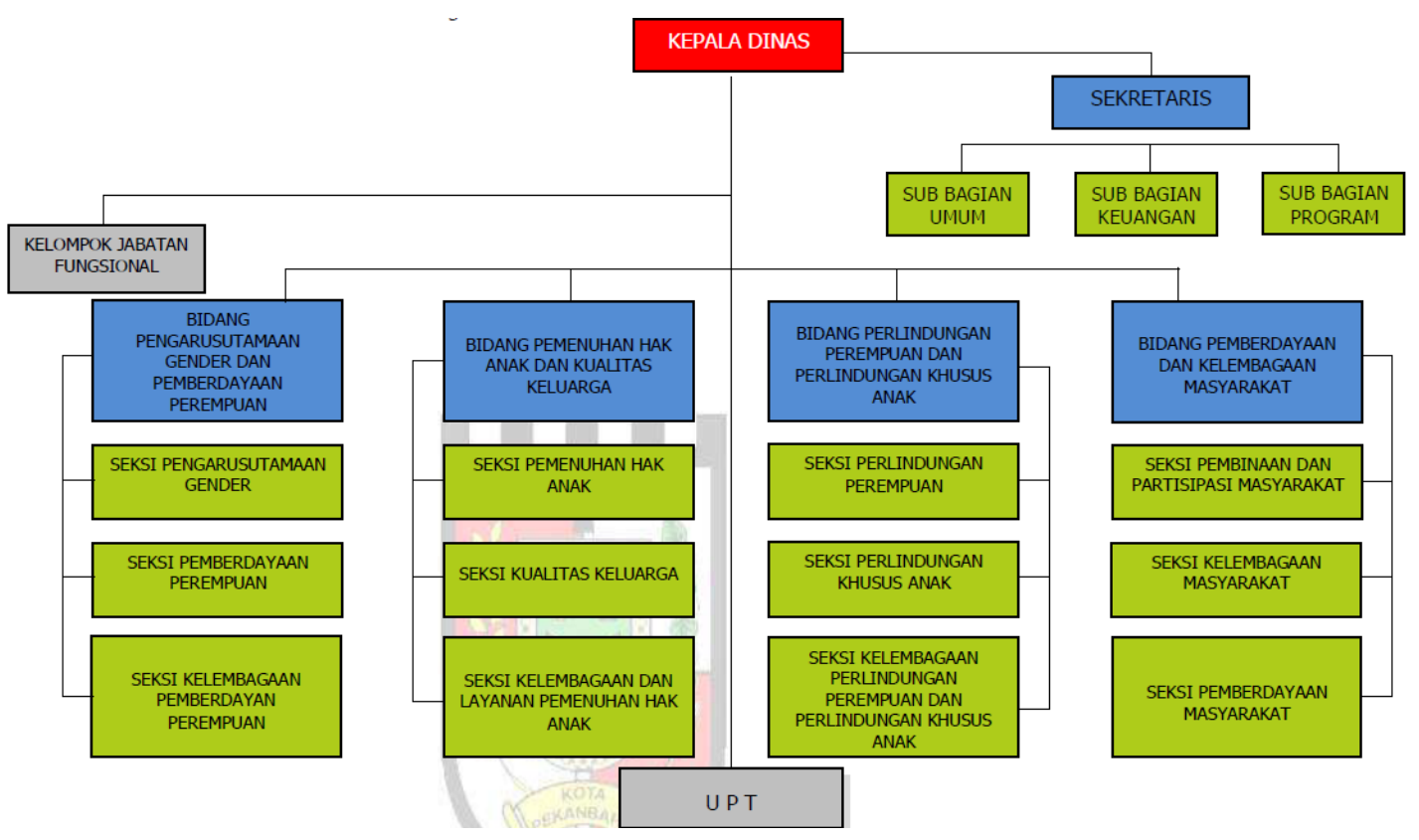

Gambar 2. Struktur Organisasi DP3A Kota Pekanbaru

Sumber : DP3A Kota Pekanbaru, 2021

Untuk mempercepat terwujudnya kesetaraan dan keadilan gender, PUG didukung oleh lembaga lainnya sebagaimana diamanatkan dalam Peraturan Menteri Dalam Negeri Nomor 15 Tahun 2008 tentang Pedoman Pelaksanaan PUG di daerah. untuk pelaksanaan amanat tersebut di daerah dibentuk kelompok kerja (pokja) PUG berdasarkan Surat Keputusan Walikota Pekanbaru Nomor 228 Tahun 2020. Pokja PUG diketuai oleh Bappeda, DP3A sebagai sekretaris dan seluruh OPD sebagai anggota Pokja. Selain itu Pokja ini juga melibatkan masyarakat dan perguruan tinggi. Faktanya Pokja PUG belum memiliki rencana kerja yang jelas sebagai pedoman pelaksanaan kebijakan PUG sehingga masing-masing OPD yang terkait terkesan berjalan sendiri-sendiri. Kelembagaan lainnya yang dibentuk adalah driver PUG yang beranggotakan Bappeda, DPPPA, Inspektorat dan BPKAD. Pembentukan driver PUG bertujuan untuk menjamin pelaksanaan PUG dalam perencanaan dan penganggaran serta mendorong terbentuknya komitmen pimpinan dalam melaksanakan PUG. Pada level OPD dibentuk focal point yang merupakan pejabat yang membidangi perencanaan (Kepala Sub Bagian Program). Pada tahun 2020, sudah semua OPD memiliki focal point PUG (45 focal point).

Berdasarkan uraian diatas, Pemerintah Kota Pekanbaru telah memiliki kelembagaan yang lengkap sebagai prasyarat pelaksanaan PUG namun berbagai bentuk kelembagaan tersebut belum optimal menjalankan perannya masingmasing. Beberapa permasalahan yang dihadapi, yaitu: perbedaan persepsi, lemahnya komitmen, belum memiliki rencana kerja dan mutasi pegawai. Setyawan et al., (2018) menemukan mutasi mengakibatkan terputusnya transfer pengetahuan tentang pelaksanaan PUG. 
Beberapa wujud Pelaksanaan PUG dari aspek kelembagaan dapat dilihat dari keberadaan beberapa lembaga teknis baik pemerintah maupun non pemerintah sebagai berikut:

- Unit Pelaksana Teknis Daerah (UPTD) Perlindungan Perempuan Dan Anak Kota Pekanbaru

- Rumah Sakit Daerah Madani Kota Pekanbaru

- $\quad$ Puskesmas Simpang Tiga, Ri Sidomulyo, Tenayan Raya, Sapta Taruna, Karya Wanita, Rejosari

- Women Crisis Center : Lembaga Bantuan Hukum Anak Riau (LBPAR), Lembaga Perlindungan Anak (LPA)

- Lembaga advokasi hukum : LBH Kerakyatan

Selain itu wujud pelaksanaan PUG dari aspek pelayanan dilihat dari ketersediaan fasilitas layanan publik bagi lbu dan Anak seperti ruang bermain dan ruang menyusui. Kantor perangkat daerah yang memiliki fasilitas layanan ibu dan anak seperti Dinas Kependudukan dan Pencatatan Sipil Kota Pekanbaru dan Badan Penanaman Modal PTSP Kota Pekanbaru

\section{Sistem Informasi dan Tool}

Salah satu unsur penting dalam pelaksanaan PUG adalah ketersediaan data terpilah namun ketersediaan data tersebut masih belum menjadi perhatian SKPD. Temuan ini sama dengan hasil penelitian Harya (2018). Penyebarluasan informasi PUG baik cetak maupun elektronik didukung oleh regulasi dan website pemerintah daerah. Kota Pekanbaru telah menyusun Peraturan Nomor 91 Tahun 2018 tentang Satu Data Kota Pekanbaru, Keputusan Walikota Nomor 94 Tahun 2018 tentang Pembentukan Tim Pengelola Informasi dan Dokumentasi Kota Pekanbaru, Web site kota Pekanbaru https://www.pekanbaru.go.id dan Web site DP3A https://dp3apm.pekanbaru.go.id/.

\section{Pedoman dan Metode}

DP3A telah menyusun beberapa pedoman dan panduan pelaksanaan PUG didaerah. Pedoman tersebut merupakan penjabaran dari pedoman dan panduan yang dikeluarkan oleh pemerintah pusat. Beberapa pedoman yang telah disusun yaitu: Buku Panduan Pelaksanaan PUG di daerah, Pedoman Teknis Pelaksanaan Perencanaan dan Penganggaran Responsif Gender di Daerah, Model Pelatihan Integrasi Gender Dalam Perencanaan dan Pengantar dengan pendekatan Three Ends Plus, Modul Pelatihan Perencanaan Daerah yang Responsif Gender (PPRG), Pedoman Pengawasan Pelaksanaan Perencanaan dan Penganggaran yang Responsive Gender untuk Pemerintah Daerah.

Penyusunan anggaran sudah dilakukan melalui analisis gender dengan alat analisis Gender Analysis Pathway (GAP). Gender Analysis Pathway (GAP) adalah suatu alat analisis gender yang dapat digunakan untuk membantu para perencana dalam melakukan pengarusutamaan gender dalam perencanaan kebijakan/ program/ kegiatan pembangunan (Maulana \& Ibrahim, 2018). Penerapan GAP dalam penyusunan penganggaran masih terkendala dengan kemampuan SDM 
yang terbatas dalam melakukan analisis gender menggunakan tool GAP yang dirasa sulit dan rumit (Muhartono, 2020).

\section{Sumber Daya Manusia dan Anggaran}

Aspek Sumber Daya Manusia

SDM PUG masih terbatas jumlahnya sehingga belum optimal dalam mendampingi OPD dalam penyusunan perencanaan penganggaran responsif gender (PPRG). SDM PUG yang dimiliki yaitu SDM aparatur terlatih dan memiliki sertifikasi PPRG sebanyak 45 orang yang berada pada masing-masing SKPD, 1 orang fasilitator tingkat kota dan 2 orang fasilitator tingkat provinsi yang berasl dari perguruan tinggi. Secara kualitas, SDM PUG masih terbatas khususnya dalam menyusun PPRG dan Anggaran Berbasis Gender. Untuk mengatasi keterbatasan kemampuan SDM tersebut, Dinas P3A dan Bappeda telah melakukan sosialisasi, pelatihan dan pendampingan kepada SKPD namun masih terkendala dengan keterbatasan anggaran. Hasil penelitian yang sama juga ditemukan oleh (Harya, 2018).

\section{Aspek Anggaran}

Dari aspek anggaran, penyusunan anggaran sudah dilakukan dengan alat analisis Gender Analysis Pathway (GAP). Tabel 1 menunjukkan penerapan GAP pada program, kegiatan dan anggaran secara kuantitatif meningkat selama dua tahun terakhir seiring dengan peningkatan jumlah OPD (Organisasi Perangkat Daerah) yang menerapkan GAP. Namun demikian persentase anggaran berperspektif gender masih minim. Hasil temuan ini sama dengan kesimpulan Khaerah \& Mutiarin, (2016) yang menyatakan bahwa anggaran daerah belum memiliki perspektif gender. Kondisi tersebut disebabkan karena jumlah program dan kegiatan yang menerapkan GAP pada masing-masing OPD rata-rata berjumlah 1 s.d 3 kegiatan.

Tabel 1 Penerapan GAP dalam Perencanaan dan Penganggaran di Kota Pekanbaru 2019 s.d 2020

\begin{tabular}{lcc}
\hline \multicolumn{1}{c}{ Penerapan GAP } & Tahun & $\mathbf{2 0 2 0}$ \\
\hline Program & $\mathbf{2 0 1 9}$ & 58 program \\
Kegiatan & 43 program & 161 kegiatan \\
Anggaran & 58 kegiatan & Rp. 132.688 .931 .785 \\
OPD & Rp. 61.520 .268 .954$)$ & $45(100 \%)$ \\
\hline
\end{tabular}

Sumber: Bappeda, 2021

Selanjutnya masing-masing OPD yang menjadi Dirver PUG juga mengalokasikan anggaran untuk mendukung pelaksanaan PUG meskipun anggaran tersebut juga masih minim. Adapun jumlah dan persentase anggaran pendukung pelaksanaan PUG pada masing-masing OPD Driver PUG yaitu: Dinas PPPA Rp 856.450.645 (22\%), Bappeda Rp 487.000,000 (13\%), Badan Pengelola Keuangan dan Aset Daerah sebesar Rp 337.796 .500 (4\%) dan Inspektorat sebesar Rp 150.000.000 (8\%). 


\section{Partisipasi Masyarakat}

Keterlibatan perguruan tinggi, dunia usaha dan LSM dalam pelaksanaan PUG kota Pekanbaru dapat dilihat dalam bentuk kegiatan Pendidikan gender, penelitian, pemberdayaan masyarakat dan pembinaan UMKM. Disamping itu untuk menampung aspirasi dan peran serta masyarakat telah dibentuk Forum Komunikasi Partisipasi Publik Untuk Kesejahteraan Perempuan dan Anak Payung Negeri Kota Pekanbaru .

\section{KESIMPULAN}

Pemerintah Kota Pekanbaru memiliki komitmen mewujudkan kesetaraan gender melalui pengintegrasian PUG dalam dokumen perencanaan, penganggaran dan pelaksanaan pembangunan namun berdasarkan hasil evaluasi terhadap capaian tujuh indikator kunci prasyarat PUG, masih terdapat capaian indikator yang belum optimal seperti komitmen dan dukungan politik serta SDM.

Untuk mengoptimalkan capaian tersebut, penelitian ini merekomendasikan beberapa hal, yaitu: 1. Perlu dibentuk Peraturan Daerah tentang Pelaksanaan Pengarusutamaan Gender (PUG) di kota Pekanbaru yang manjadi landasan dan acuan dalam percepatan pelaksanaan PUG di kota Pekanbaru; 2. Perlu mendorong munculnya Inovasi - inovasi berbasis kearifan lokal guna mendukung pelaksanaan pengarusutamaan gender (PUG) di daerah; 3. Perlu peningkatan kualitas dan kuantitas SDM yang mendukung pelaksanaan PUG khususnya penambahan jumlah fasilitator PUG yang memberikan pendampingan terkait pengarusutamaan gender pada masing-masing perangkat daerah di kota Pekanbaru.

\section{UCAPAN TERIMAKASIH}

Ucapan terimakasih Penulis kepada stakeholders terkait yang telah berkontribusi terhadap penelitian dan penulisan artikel ini khususnya pejabat dari Bappeda Kota Pekanbaru dan DP3A Kota Pekanbaru.

\section{DAFTAR PUSTAKA}

(1) Annisa, D., Noer, M., \& Andrianus, F. (2021). Evaluasi Pelaksanaan Pengarusutamaan Gender Pada Program Kampung Keluarga Berencana Kota Bukittinggi (Evaluation of the Implementation of Gender Mainstreaming in the Family Planning Village Program in Bukittinggi City. Menara Ilmu, 15(01), 19-31. https://doi.org/https://doi.org/10.31869/mi.v15i1.2352

(2) Apriliandra, S., \& Krisnani, H. (2021). Perilaku Diskriminatif Pada Perempuan Akibat Kuatnya Budaya Patriarki di Indonesia di Tinjau dari Perspektif Konflik. Jurnal Kolaborasi Resolusi Konflik, 3(1), 1. https://doi.org/10.24198/jkrk.v3i1.31968

(3) Arenawati, Prafitri, N., \& Widyastuti, Y. (2020). Affirmative Action untuk Mengurangi Disparitas Gender dalam Politik di Kota Serang. Jurnal Administrasi Dan Kebijakan, V(1), 75-85. https://doi.org/10.25077/jakp 
(4) Azmy, A. S., \& Pertiwi, F. (2021). Implementasi Kebijakan Pengarusutamaan Gender (PUG) DiBidang Pendidikan di Kota Bogor. Marwah: Jurnal Perempuan, Agama Dan Jender, 19(2), 160. https://doi.org/10.24014/marwah.v19i2.10699

(5) Bappenas. (2020). Lampiran Pidato Presiden Republik Indonesia 2020

(6) Darwin, M. (2006). Memperkecil Kesenjangan Gender Melalui Kebijakan Pengarusutamaan Gender (PUG). Jurnal Penyuluhan, 2(1).

(7) Dini, I. M., Fajriyah, Sylvianti, A., \& Lukitasari, I. (2020). Pembangunan Berbasis Gender (I. M. Dini, Fajriyah, A. Sylvianti, \& I. Lukitasari (eds.)). Kementerian Pemberdayaan Perempuan dan Perlindungan Anak Republik Indonesia.

(8) Dzuhayatin, S. R. (2012). Kesetaraan Gender: Kontestasi Rezim Internasional dan Nilai Lokal. Musawa, 11(2).

(9) Hanafie, S. R. M. J. (2017). Rencana Aksi Daerah Pengarusutamaan Gender Kabupaten Mojokerto Tahun 2017. Jurnal IImiah Sosio Agribis, 17(1), 53-69. https://doi.org/10.30742/jisa.v17i1.380

(10) Harya, G. I. (2018). Rencana Aksi Daerah Pengarusutamaan Gender Kabupaten Pacitan. Journal Sosioagribis, 18(2), 51-73.

(11) Hasanah, U., \& Musyafak, N. (2018). Gender and Politics: Keterlibatan Perempuan dalam Pembangunan Politik. Sawwa: Jurnal Studi Gender, 12(3), 409. https://doi.org/10.21580/sa.v12i3.2080

(12) Hidayah, R. (2008). Perempuan dan Keterwakilannya dalam Politik Praktis. Egalita Jurnal Kesetaraan Dan Keadilan Gender, 3(2), 1-14. https://doi.org/10.18860/egalita.v0i0.1978

(13) Karyono, Y., Tusianti, E., Clarissa, A., \& Rahmawati, D. N. (2018). Penghitungan Indeks Ketimpangan Gender 2018 (Kajian Lanjutan 2) (S. direktorat A. Statistik (ed.)). Badan Pusat Statistik Indonesia.

(14) Kertati, I. (2019). Evaluasi Penyelenggaraan Pengarusutamaan Gender (PUG) Kota Semarang. Jurnal Riptek, 13(1), 57-64.

(15) Kertati, I. (2021). Analisis Indeks Pembangunan Gender ( IPG ) dan Indeks Pemberdayaan Gender ( IDG ) Kota Surakarta. Public Service and Governance Journal, Vol 2(1), 1-11

(16) Khaerah, N., \& Mutiarin, D. (2016). Integrasi Anggaran Responsif Gender Dalam Anggaran Pendapatan Belanja Daerah. Journal of Governance and Public Policy, 3(3), 413-445. https://doi.org/10.18196/jgpp.2016.0065

(17) Luh, N., Ifa, K., \& Erviantono, T. (2019). Persepsi Anggota Legislatif Laki-laki terhadap Pengarusutamaan Gender di DPRD Provinsi Bali Periode 2014-2019. 1-12.

(18) Maulana, U. I. N., \& Ibrahim, M. (2018). Pendampingan Perencanaan dan Penganggaran Responsif Gender di Kantor Kementerian Agama. 13(1), 14-23.

(19) Muhartono, D. S. (2020). Pentingnya Regulasi Pengarusutamaan Gender dalam Pembangunan Daerah di Kabupaten Kediri. Jurnal IImu Sosial Dan IImu Politik, 3(2), 117-134.

(20) Musarrofa, I. (2019). Pemikiran Pierre Bourdieu Tentang Dominasi Maskulin dan Sumbangannya Bagi Agenda Pengarusutamaan Gender di Indonesia. Kafa`ah: Journal of Gender Studies, 9(1), 34. https://doi.org/10.15548/jk.v9i1.227

(21) Normadilla, N., \& Erlina. (2020). Gender Analysis in Indonesia's Legislation Regarding Political Laws. 7(3), 337-354. https://doi.org/https://doi.org/10.19184/ejlh.v713.20117

(22) Rahayu, W. K. (2017). Analisis Pengarusutamaan Gender dalam Kebijakan Publik (Studi Kasus di BP3AKB Provinsi Jawa Tengah). JAKPP (Jurnal Analisis Kebijakan \& Pelayanan Publik), 2(1), 93-108. http://journal.unhas.ac.id/index.php/jakpp/article/view/1524 
(23) Roza, Y., \& Lutfi., R. B. (2016). Pelaksanaan Program Sekolah Berwawasan Gender di Provinsi Riau. Marwah, 2(Desember), 173-188.

https://doi.org/http://dx.doi.org/10.24014/marwah.v15i2.2646

(24) Santi, E. T. (2020). Representasi Citra Politisi Perempuan di Parlemen (Analisis Framing dalam Pemberitaan VoAlndonesia.com dan Medialndonesia.com). Dialektika Komunika: Jurnal Kajian Komunikasi Dan Pembangunan Daerah, 7(2), 22-32. https://doi.org/10.33592/dk.v7i2.357

(25) Santoso, W. M. (2016). Penelitian dan Pengarusutamaan Gender: Sebuah Pengantar. LIPI Press.

(26) Setyawan, D., Firdausi, F., \& Rusmiwari, S. (2018). Analisis Program Perencanaan Penganggaran Responsif Gender. Jurnal Ilmu Administrasi Publik, 3(1), 64-72. https://doi.org/http://dx.doi.org/10.26905/pjiap.v3i1.2275

(27) Tamami, M. (2015). Dilema Pembangunan Berwawasan Gender: Antara Pemberdayaan dan Eksploitasi Perempuan. Harkat: Media Komunikasi Islam Tentang Gender Dan Anak, 11(2), 128-138. https://doi.org/https://doi.org/10.15408/harkat.v11i2.10437

(28) Tawakkal, N., Darma, R., \& Nurbayani, S. U. (2019). Model Sinergitas Pengarusutamaan Gender dalam Mewujudkan Keadilan dan Kesetaraan Pendidikan. 31(1), 153-166.

(29) Tusianti, E. (2020). Kajian Penghitungan Indeks Ketimpangan Gender (Subdirektorat Analisis Statistik (ed.)). BPS RI.

(30) Vera, A., \& Sitorus, Y. (2010). Dampak ketimpangan gender terhadap pertumbuhan ekonomi di indonesia. 89-101.

(31) Wisnujati, N. S. (2020). Penyusunan Indeks Pemberdayaan Gender dan Indeks Pembangunan Kabupaten Bojonegoro. Journal Sosioagribis, 20(2), 67-81.

(32) Ylöstalo, H., \& Ylöstalo, H. (2016). Organizational perspective to gender mainstreaming in the Finnish state administration the Finnish state administration. 6742(June). https://doi.org/10.1080/14616742.2016.1149307 